\title{
Empowerment of Youth Agribusiness Entrepreneurs Using Social Capital Based Business Models Canvas in North Sulawesi
}

\author{
Joseph Arteurt Merung1*, Dwi Putra Darmawan², Wayan Windia², Ni Wayan Sri Astiti² \\ ${ }^{1}$ Doctoral Study Program of Agricultural Science, Udayana University, Bali, Indonesia \\ ${ }^{2}$ Faculty of Agriculture, Udayana University, Bali, Indonesia \\ Email: *a.merung@gmail.com
}

How to cite this paper: Merung, J.A., Darmawan, D.P., Windia, W. and Astiti, N.W.S. (2019) Empowerment of Youth Agribusiness Entrepreneurs Using Social Capital Based Business Models Canvas in North Sulawesi. Modern Economy, 10, 347-358.

https://doi.org/10.4236/me.2019.102023

Received: December 11, 2018

Accepted: January 28, 2019

Published: January 31, 2019

Copyright $\odot 2019$ by author(s) and Scientific Research Publishing Inc. This work is licensed under the Creative Commons Attribution International License (CC BY 4.0).

http://creativecommons.org/licenses/by/4.0/

\begin{abstract}
The purpose of this study was to engineer a social capital-based canvas business model that is oriented towards the value of products offered to customers and devised a strategy to empower young entrepreneurs to develop their business in Manado, North Sulawesi, in 2018. ANP (analytical network process) analysis was chosen as a decision analysis tool engineer of this business system. ANP allows dependencies and feedback, both between elements in the cluster (inner dependence) and between clusters (outer dependence). Supermatrix, with all its advantages, is a fundamental tool in ANP. Based on the results of the study produced a canvas business model based on participation in social networks, oriented to the value of product creation offered to customers, and supported by the empowerment of entrepreneurial competencies for young entrepreneurs, business infrastructure development, and social innovation. Continuously, it is necessary to validate model assumptions with customers in order to represent the potential of a social-based canvas model business in North Sulawesi.
\end{abstract}

\section{Keywords}

Youth Agribusiness Entrepreneurs, Social Based Business Models Canvas, Empowerment Strategy

\section{Introduction}

Economic development of a country cannot be separated from the role of entrepreneurship, small, medium and large. In macro, entrepreneurship can help contribute to the provision of employment. In micro, entrepreneurship results in a person with a hard-working character with high self-confidence and indepen- 
dence in trying. The higher the opportunity for people to produce and generate income, the more narrow the gap between high and low-income people. With the growth and development of the business world due to the presence of entrepreneurs, it can create prospective business opportunities, contribute to the availability of employment, and in turn have an impact on the local, regional and national economy. With the increasingly strong entrepreneurship, the national economy will be stronger so that it can reduce Indonesia's dependence on other countries.

The current era is an era of disruption; an era where those who were unable to turn to face a competitor would retreat by themselves, then disappear. The disruption causes the effects of destruction or shifts to occur faster. Anyone who is a passenger minded and caretaker will be increasingly evicted and make a business or service die [1]. The era of disruption has given rise to a positive effect on the emergence of new creative and innovative businesses, not least in the field of agribusiness that utilizes information technology and is mostly managed by young people known as startups.

In Indonesia, entrepreneurship began to become popular since Indonesia began the reform era. Since that time, it is realized that the importance of MSMEs is an important support for the Indonesian economy and since that time entrepreneurship has been encouraged. The economic crisis experienced by Indonesia in 1998 resulted in layoffs everywhere. Many large companies go bankrupt. This condition actually becomes a trigger for workers who lose their jobs to turn into entrepreneurs in the field of handicraft, creative economy, tourism, commerce and culinary, and agribusiness. Since then entrepreneurship in the field of agribusiness in Indonesia has grown rapidly. Agribusiness entrepreneurs in Indonesia are actually interesting entrepreneurs to live because, as a country dominated by agricultural products, of course, there are sufficient raw materials to try. Business in the field of agricultural commodities is a prospective potential.

The development of agribusiness entrepreneurs, mainly carried out by young people in the Sulawesi region, can at least be seen in two major cities, namely Manado and Makassar. In these two cities, young entrepreneurs in agribusiness are mostly engaged in agricultural products [2]. However, in general, the young movement that runs this business is still sporadic. The younger generation is the generation of change and in the younger generation entrepreneurial souls are easily grown [3]. Laying the foundation of the character must begin from youth. Entrepreneurship is never separated from creativity and innovation and can only develop if the young generation is given the opportunity to develop. Entrepreneurial competence can be instilled through training/education and entrepreneurship empowerment in order to give birth to young people who are able to create and develop businesses in the field of agribusiness. Thus, it is hoped that the paradigm of the Indonesian people will change, initially as job seekers to become job providers.

Canadian International Development Agency (CIDA) pioneered a five-year project (2012-2017) devoted to the Sulawesi region. This project is called the 
Sulawesi Economic Development Strategy Project (SEDS), in collaboration with the Humber Institute of Technology, a trusted educational institution in Canada and based in Toronto. In North Sulawesi, the SEDS Project involved four leading universities, namely Sam Ratulangi University Manado (UNSRAT), Manado State University (UNIMA), De La Salle Catholic University (DLSU), Klabat University (UNKLAB), while in South Sulawesi, the University Hasanuddin (UNHAS), Muhammadiyah University (UNISMUH) Makassar and Makassar State University (UNM). The main objective of this project is to increase the capacity of universities involved in academic programs and equip graduates with applied entrepreneurial skills. Every institution, through strengthening the curriculum, is expected to be able to produce independent young entrepreneurs.

In the implementation of the SEDS project activities, the main program is to direct students to create their own businesses, including business in the field of agribusiness. Students are expected to be independent individuals and dare to build their own business accompanied by lecturers who are coached by the SEDS program. Through mentoring, every student who will undergo a new business refers to the business model approach to make it easier for them to describe the business they are going to run. By designing a business model scientifically, an entrepreneur can more easily build his business idea portfolio so that it is more focused and strategic for the success of his business. The business model can be interpreted as a prototype that will be used by young entrepreneurs to describe briefly how the business is running in creating value for the company's stakeholders related to the entrepreneur [1]. The success of large companies controlling the market or startup companies, such as Bukalapak, Tokopedia, Kaskus, Bli-bli, Shopee, and other startup businesses, actually lies in how the creator (owner/entrepreneur) designs the business model of his business [4].

The current national development program is directed more towards the eastern part of Indonesia. Sulawesi, as one of the major islands in the East, is now used by the central government as one of the entrances to the country's economy because its strategic position is directly facing the Pacific Ocean. A great opportunity is encountered, especially when facing the economic expansion of China which is now one of the world economic powers. North Sulawesi has now become one of the country's investment targets because of its strategic position directly facing the Chinese sea. Efforts to increase investment from abroad are also inseparable from the role of Indonesian Research and Development International (IRDI) which encourages Chinese investors to invest in Sulawesi. Facing this very potential opportunity, one that must be strengthened is young entrepreneurs. The emergence of new businesses becomes something that must be appreciated with various empowerments. One that can be done is through a business model approach.

One business model that is well known and widely used lately is the canvas business model. This canvas business model is also applied in the assistance activities of SEDS participants, both in theorists and their applications. The canvas business model was first introduced by Osterwalder [5] in his book entitled 
Business Model Generation. In its application to SEDS participants, an entrepreneur or prospective young entrepreneur clearly outlines his business plan, and even opens his insight into seeing business opportunities. The business model canvas (BMC) introduced by Osterwalder [6] is a tool for creating and analyzing business models. BMC describes the logical possibility of how an organization creates, delivers, and maintains (creates, delivers and preserves) the value produced. A BMC that adopts a part of design science is able to illustrate the rationale for how organizations can create, deliver, and captures product values (Saif, 2011). BMC presents a canvas to describe, visualize, develop, and explore business models.

However, the canvas business model is one of the most abundant and easy to use business models for entrepreneurs, at least in the past decade it has not been able to bridge the main barriers of entrepreneurs, especially young entrepreneurs [2] [7]. In its implementation, the main obstacle faced by young entrepreneurs built through the SEDS program is capital constraints. However, capital in doing business can actually be seen from money and non-money. Capital can also be seen as economic capital and non-economic capital. Non-economic capital that is related to society is social capital [8]. Hasbullah [9] which states that social capital can be in the form of elements, namely trusts, participation in networks, norms, values, proactive action, and reciprocity. Putnam [10] states that social capital is a feature of social organization, in the form of networks, norms, and social beliefs that can facilitate coordination and cooperation for mutual benefits. Human capital is more about the capacity of the person concerned, while social capital is seen more like an interaction. In this regard, the use of social capital needs to be designed in the form of a structured approach model to be applied in empowering a new business [11] [12]. The approach to trust, participation in networks, norms, values, proactive actions and reciprocity [9] is very possible to be a way to empower entrepreneurs, especially young entrepreneurs.

Therefore, a new method is needed, as a social business model as one of the methods of empowering young entrepreneurs in North Sulawesi, without overriding the benefits of the existing canvas model business. The canvas business model that is integrated with the social capital that is formed, is then used as a design platform for empowering the empowerment of young agribusiness entrepreneurs.

The purpose of this research is to engineer a canvas-based social capital business model that is oriented towards the value of products offered to customers and to design strategies to empower young entrepreneurs to develop their business in Manado, North Sulawesi.

\section{Method}

This research was conducted in Manado, North Sulawesi. Location determination was done purposively because the SEDS project considered this city to be a representation of development in eastern Indonesia, especially on the island of 
Sulawesi. The research was conducted in December 2017-May 2018. Respondents were selected purposively to conduct expert meetings consisting of elements of the local government, c.q. Agriculture, Disperindag, Dinas UMKM, DPRD, trained students and SEDS participant lecturers who do business according to the direction of the SEDS project, traders/exporters, processors, consumers, and experts in the field of agribusiness entrepreneurship and social capital involved, both directly and indirectly directly in the SEDS project.

\subsection{Data Collection Technique}

The critical review of relevant reports published and the results of field observations is a reference for the analysis of the needs of young entrepreneurial empowerment, as well as a plan for fulfillment strategies in North Sulawesi. Data are grouped on primary and secondary data relating to the development of the canvas business model, the SEDS project report and relevant references, expert opinion preferences, and using a consensus method in determining the valuation. Data collection is in accordance with the research objectives by using the Appreciative Inquiry method [13], through 1) rapid research, commensurate with the Rapid Rural Appraisal (RRA) method which involves a multidisciplinary team in collecting and analyzing causal logical data in a short time; 2) in-depth interviews and direct observation at the place of business and Entrepreneurship Center (EC); 3) participatory workshops, commensurate with Sigma-5-based Interactive Management (IM) (facilitators, demosophia/situation rooms, computers, consensus methodologies, and expert groups) and a well-documented root cause process [14] [15]; 4) peer review is conducted twice, namely during rapid research and participatory workshops to select the right elements of business system development as well as to make a business plan.

\subsection{Data Analysis}

In this study, ANP (Analytical Network Process) analysis was chosen as a decision analysis tool for the development of a canvas business model based on social capital in North Sulawesi. The network analytic model has been widely applied in decision making for companies, governments, and society [16] [17] [18] [19] [20]. ANP allows an analyst to include all factors and criteria, both tangible and intangible, regarding the best decision-making system development. ANP allows dependencies and feedback, both between elements in the cluster (inner dependence) and between clusters (outer dependence). Feedback is able to capture the influence of interaction, especially when decision makers are faced with the risks and uncertainties in a complex business environment. ANP has three parts, namely strategic criteria, control criteria, and decision networks that determine the priority of decision alternatives. Priority strategic criteria and control criteria are used to synthesize alternative priorities to obtain the best final answer. Supermatrix, with all its advantages, is a fundamental tool in the ANP [21] [22] [23] [24]. Data analysis was carried out with Super Decisions version 
3.0 (designed by Bill Adam and The Creative Decision Foundation) software tools. The results of the expert meeting at the IM session were used as input to form the ANP model of canvas based on social capital business models, including engineering dependency and feedback relationships between three clusters in the model, namely (a) business model canvas cluster (having 9 elements, namely: customer segments, value propositions, channels, customer relationships, revenue streams, key resources, key activities, key partners, and cost structures), social capital clusters (with 3 elements: trusts, norms, and networks), and alternative clusters of young entrepreneurial empowerment strategies (with 3 value elements: Creating, Delivering, and Preserves) as an integrated solution for developing a canvas business model based on social capital in North Sulawesi.

\section{Results and Discussion}

\subsection{Results}

\subsubsection{Building the ANP-Social Capital Based Business Model Canvas}

ANP network model-Social Capital Based Business Model Canvas (ANP-SCBMC) (Figure 1) was built to choose the best priority empowerment strategy from 3 value-based empowerment strategy alternatives Creates, Delivers, and Perserves that are interrelated with each other by paying attention cluster The BM Canvas and Social capital along with the elements. This model places clusters and elements (a.k.a node) each in a single window (no sub-network). In Figure 1, there is a loop that shows the inner dependence between elements in clusters that are parent nodes. The relationship between inner dependence and outer dependence of the ANP-SCBMC model in the Super Decisions software is marked in red.

\subsubsection{Final Comparison Results of Elements and Clusters and Model Stability}

Pairwise comparisons for each element in each parent node are performed for all parent nodes in the model. All comparison questions are reviewed from the perspective of what is important or preferred with respect to alternative empowerment strategies. Data obtained from preference expressions comparing pairs of experts in IM sessions were entered into each cell on Questionnaire Super Decisions mode. To produce a validated ANP-SCBMC model, the tolerated inconsistency index results of expert preferences are $<0.1$ ) [24].

Model stability analysis is carried out to ensure the stability of the results of this social capital-based canvas business ANP model. Model stability analysis shows that if one of the priorities of the meaningful control criteria is used as an independent variable (one variable is raised or reduced in weight, while the other is proportionally fixed, a.k.a ceteris paribus), the best alternative remains stable (remained stable). Sensitivity analysis carried out at the level of the control criteria shows that if the priority level of the control criteria is meaningfully changed, the choice of empowerment strategy by creating product values remains dominant and does not change the overall empowerment strategy alternative 


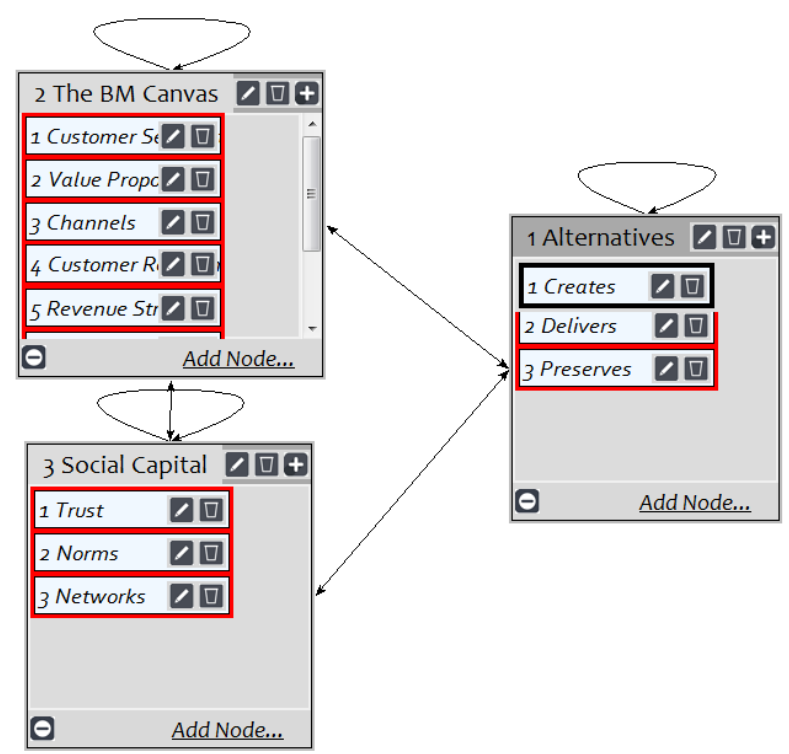

Figure 1. The ANP-Social Capital Based Business model canvas (The ANP-SCBMC model).

rankings unless the extreme priority change assumptions are used on the control criteria.

Cluster comparison is done by selecting each cluster as the parent node and making a pairwise comparison with all the clusters connected to analyze 'which is more influencing alternative empowerment strategies, elements of Business Model Canvas or Social Capital?' The results show that SC (0.4434) is more important than with BMC (0.3874) in influencing alternative empowerment strategies. The priority strategies for empowering cross-cluster and element young entrepreneurs (normalized by clusters) are presented in Table 1.

The application of the ANP-SCBMC model produces the highest priority of the cluster The BM Canvas is the element of customer segments (0.2000), successively followed by values proposition, channels, customer relationship, revenue streams, key resources, key activities, key partners, and cost structure, while for social capital clusters, the highest priority is for elements of Networks (0.4666), followed by trusts and norms. The overall synthesis for the best empowerment strategy alternative is to create (0.4870), followed deliver (0.3174), and preserves $(0.1956)$ the value generated by the ANP-SCBMC model.

\subsection{Discussion}

Based on 9 building blocks (BB) [5], young entrepreneurs can glance at how an entrepreneur runs his business and makes a profit. Visually, the model shows how the BB is connected (interlock) and provides 'common language' to discuss the existing business model (current) and (potential) model in the future (future). In the ANP-SBMC model application, contextual relationships between elements are marked in red. At first glance, actually, the flow of the canvas business model seems simple because it places important elements of the business 
Table 1. Priorities for the Young Entrepreneur Empowerment Strategies.

\begin{tabular}{ccc}
\hline Cluster \& Element & Normalized by Cluster & Rank \\
\hline Alternatives & & \\
\hline Creates & 0.4870 & 1 \\
Delivers & 0.3174 & 2 \\
Preserves & 0.1956 & 3 \\
\hline The BM Canvas & & 1 \\
\hline Customer Segments & 0.2000 & 2 \\
Value Proposition & 0.1810 & 3 \\
Channels & 0.1307 & 4 \\
Customer Relationship & 0.0967 & 5 \\
Revenue Streams & 0.0895 & 6 \\
Key Resources & 0.0875 & 7 \\
Key Activities & 0.0812 & 8 \\
Key Partners & 0.0688 & 9 \\
Cost Structure & 0.0646 & 2 \\
\hline Social Capital & & 3 \\
Trust & 0.2516 & 1 \\
Norms & 0.2818 & \\
Networks & 0.4666 & \\
\hline
\end{tabular}

that will be run on a canvas. Broadly speaking, the flow flows from one business element to the next important element. Osterwalder and Pigneur [5], suggested that business models are a way of describing the rationale for how organizations create, deliver, and capture value. Business models are like blueprint strategies that are applied through organizational structures, processes, and systems. Today is the era of business model battles and Osterwalder and Pigneur [5] offer a simple framework for presenting the important elements contained in a business model with the aim of providing a management strategy tool that describes, designs, and then purifies several aspects of the business into one intact business strategy. BMC became popular because of its visualization capabilities, integrated, showing how business functions. BMC is the right tool to easily produce business models, and generate new ideas and ways of doing business. BMC is also the right tool for analyzing an organization's existing business and finding new areas for improvement.

However, the implementation of MBC in the SEDS project has not been optimal as a solution to the main constraints of young entrepreneurs, namely capital, so that a new breakthrough is needed in the integration of social capital into the canvas business model to present a new method of the ANP-SBMC network model as well as the design of empowerment strategies for empowering young agribusiness entrepreneurs in North Sulawesi. Social capital clusters proved to be more dominant than BMC clusters in determining alternative empowerment. 
Participation in social networks which is one element of social capital is the key in generating strong social capital so that integrated entrepreneurship with social capital and in turn solid human capital will be able to improve the lives of people economically [8] [25] [26]. The pitfall that might be encountered in the application of a social-based canvas business model is when 9 building blocks are made based on false assumptions due to poor understanding of new customers and segments, so that the substance of the strategy for empowering selected entrepreneurs may be premature because it is too concrete and insufficient explorative [27] [28]. The ANP-SBMC model is suitable for creating alternative models and is a practical tool (hand-on tool) that helps understanding and creativity (understanding and creativity) of young entrepreneurs in North Sulawesi.

\subsubsection{Search for Young Entrepreneur Empowerment Needs and Compliance Strategy Plans}

The results of tracking the needs of young entrepreneurial empowerment are as follows: 1) the need for training in entrepreneurship competence, 2) the development of business infrastructure; 3 ) social innovation of human resources. Entrepreneurial competence plays an important role in improving the performance of young entrepreneurial businesses. The strategic plan to fulfill the empowerment needs using a strength-based solving approach is as follows.

1) Organized training on entrepreneurship competence (provided training modules): 1) personal competence, including confidence, creativity, focus on problem-solving, risk-taking, interpersonal skills, and readiness to learn; 2) technical competence, namely the ability to create inputs, the ability to increase production and processing, improve quality, accounting systems (accounting principles, transaction recording and recapitulation, financial reports, business statistics, and key performance indicators); 3) management competencies, including general planning capabilities for the development of business institutions oriented to the collective business community/socio-business, monitoring and evaluation, the ability of market networks, consumer management and marketing.

2) Development of business infrastructure, especially updating equipment and machinery for processing products and ICT infrastructure for online transactions.

3) HR social innovation, in the form of young entrepreneurial engagements, creates 1) roadmap for business development, 2) SOP for utilization of production tools and machines and SOP for added value, and 3) strategic partnership rules and regulations.

\subsubsection{The Novelty}

Based on the results of the study, the novelty was obtained in the form of a participatory network-based canvas business model oriented towards the value of product creation offered to customers and supported by the empowerment of entrepreneurial competencies for young entrepreneurs. 


\section{Conclusion and Suggestion}

\subsection{Conclusions}

Based on the results of research and discussion, conclusions can be drawn as follows.

1) The strategy of empowering young entrepreneurs through creating product value in North Sulawesi is the best alternative to empowering young entrepreneurs with a relative priority of (48.70\%), compared to an empowerment strategy in terms of delivering product value (31.74\%) and maintaining product value (19.56\%). This priority value is a comprehensive result of the ANPSBMC Model.

2) The stability analysis of the model shows that if the priorities at the level of control criteria are meaningfully changed, the choice of empowerment strategies remains dominant and does not change the overall ranking of choices unless the assumption of extreme priority changes is used.

3) The strategic plan for empowering young entrepreneurs is through a) training in entrepreneurship competence (personal competence, technical competence, and management competence); b) developing business infrastructure; c) social innovation of human resources.

\subsection{Suggestion}

Empowering young entrepreneurs through strengthening entrepreneurial competencies, needs to be continued, evaluated and the results followed up to produce premium quality products, supported by innovative product designs that are typical to support business independence and the sustainability of partnership contracts. Strengthening business through benchmarking to more advanced business institutions and strategic partnerships (production, financial facilities, and trade) needs to be continued in the context of strengthening the performance of community-based product value chains. The selection of empowerment strategies through creating product values in North Sulawesi requires multisectoral synergy. To ensure that the selection creates effective product value, the following steps are needed: a) the establishment of an integrated supply chain from entrepreneurs to consumers; b) strengthening businesses in the fields of agribusiness and marketing; c) optimizing the role of Local Government and legislatives in agribusiness production startup systems; d) the supply and rehabilitation of production system supporting facilities, including the effectiveness of the transportation system for the smooth distribution of inter-regional products.

\section{Acknowledgements}

We would like to thank CIDA through the Sulawesi Economic Development Strategy (SEDS) project for the support and provision of grants for this research.

\section{Conflicts of Interest}

The authors declare no conflicts of interest regarding the publication of this paper. 


\section{References}

[1] Kasali, R. (2017) Disruption. Kompas Gramedia, Jakarta.

[2] SEDS (2016) Final Project Report. DLSU Press, Manado.

[3] Kandampully, J. (2002) Innovation as the Core Competency of a Service Organisation: The Role of Technology, Knowledge, and Networks. European Journal of Innovation Management, 5, 18-26. https://doi.org/10.1108/14601060210415144

[4] Kasali, R. (2010) Entrepreneurship Module. Mizan Publika, Jakarta.

[5] Osterwalder, A. and Pigneur, Y. (2010) Business Model Generation: A Hand Book for Visionaries, Game Changers and Challengers. John Wiley \& Sons, New Jersey.

[6] Osterwalder, A. (2004) The Business Model Ontology-A Proportion in a Design Science Approach. University of Lausanne, Lausanne.

[7] Thobias, E., Tungka, A.K. and Rogahang, J. J. (2013) Influence of Capital on Entrepreneurial Behavior (a Study of Small and Medium-Sized Micro-Entrepreneurs in Kabaruan District, Talaud Islands District). Jurnal Acta Diurna, 2, 44-55.

[8] Fukuyama, F. (2001) Social Capital, Civil Society and Development. Third World Quarterly, 22, 7-20. https://doi.org/10.1080/713701144

[9] Hasbullah, J. (2006) Social Capital, towards the Excellence of Indonesian People. MR, Jakarta.

[10] Putnam, R.D. (2000) Bowling Alone: America's Declining Social Capital. In: Culture and Politics, Palgrave Macmillan, New York, 223-234.

[11] Torsvik, G. (2000) Social Capital and Economic Development: A Plea for the Mechanisms. Rationality and Society, 12, 451-476. https://doi.org/10.1177/104346300012004005

[12] Tohani, E. (2016) Social Capital in Community Entrepreneurship Education. Unpublished Dissertation, UNY, Yogyakarta.

[13] Roberts, G.W. (2013) Appreciative Inquiry: A New Dimension in Problem Base Learning. Cardiff University, Cardiff.

[14] Warfield, J.N. and Cardenas, A.R. (1994) A Handbook of Interactive Management. Iowa State University Press, Ames.

[15] Darmawan, D.P. (2017) Structured Decision Making with Interpretive Structural Modeling. Elmatera, Yogyakarta.

[16] Saaty, T.L. (2005) Theory and Applications of the Analytic Network Process: Decision Making with Benefits, Opportunities, Costs, and Risks. RWS Publisher, Pittsburgh.

[17] Astiti, N.W.S., Darmawan, D.P. and Sarjana, I.D.G.R. (2014) Strengthening Women's Strategic Role through Locally Specific Households Industry in Bali, Indonesia. Research on Humanities and Social Sciences, 4, 125-132.

[18] Astiti, N.W.S., Darmawan, D.P. and Sarjana, I.D.G.R. (2018) Women's Empowerment Model through Development of Households Industry Locally Specific in District of Abang, Karangasem Regency. Journal of Sociological Research, 9, 22-32. https://doi.org/10.5296/jsr.v9i2.13130

[19] Wiratanaya, G.N., Darmawan, D.P., Kolopaking, L.M. and Windia, W. (2015) Selection of Beef Production Systems in Bali: An Analytical Network with BOCR Approach. Journal of Economics and Sustainable Development, 6, 45-59.

[20] Krogerus, M. and Tschäppeler, R. (2017) The Decision Book: Fifty Models for Strategic Thinking. New and Updated Edition, Profil Books, London. 
[21] Saaty, T.L. (2001) Creative Thinking, Problem Solving \& Decision Making. RWS Publisher, Pittsburgh.

[22] Saaty, T.L. (2001) The Analytic Network Process: Decision Making with Dependence and Feedback. RWS Publisher, Pittsburgh. https://doi.org/10.1007/1-4020-0611-X_32

[23] Saaty, T.L. and Vargas, L.G. (2006) Decision Making with the Analytic Network Process: Economic, Political, Social and Technological Applications with Benefits, Opportunities, Costs and Risks. Springer, New York.

[24] Darmawan, D.P. (2018) The Analytic Network Process for Decision Making in Complex Environments. GrahaIlmu, Yogyakarta.

[25] Qianhong, F. (2004) Trust, Social Capital and Organizational Effectiveness. Virginia Polytechnic Institute, Virginia.

[26] Lukatela, A. (2007) The Importance of Trust-Building in Transition: A Look at Social Capital and Democratic Action in Eastern Europe. Canadian Slavonic Papers, 49, 49-68. https://doi.org/10.1080/00085006.2007.11092430

[27] Kaplan, R.S. and Norton, D.P. (2000) Having Trouble with Your Strategy? Then Map It. Harvard Business Review, 78, 167-176.

[28] Kaplan, R.S. and Norton, D.P. (2004) Strategy Maps. Harvard Business School Press, Boston. 